\title{
CHLAMYDIALES - TAXONOMY, PATHOGENICITY, AND ZOONOTIC POTENTIAL
}

\author{
KRZYSZTOF NIEMCZUK, MARIAN TRUSZCZYŃSKI, \\ AND MONIKA SZYMAŃSKA-CZERWIŃSKA \\ National Veterinary Research Institute, 24-100 Pulawy, Poland \\ kniem@piwet.pulawy.pl
}

Received: August 27, 2012

Accepted: September 9, 2012

\begin{abstract}
Changes in the taxonomy of the order Chlamydiales, after its separation from the order Rickettsiales, were presented. These changes resulted in the recognition of the following families: Chlamydiaceae, Chlavichlamydiaceae, Criblamydiaceae, Parachlamydiaceae, Piscichlamydiaceae, Rhabdochlamydiaceae, Simkaniaceae, and Waddliaceae. Other described changes concerned particularly the family Chlamydiaceae. Its genus Chlamydia was divided into Chlamydia and Chlamydophila. However, in the following years, a revision to the single original genus was made, based upon phylogenetic analysis of $16 \mathrm{~S}$ and $23 \mathrm{~S}$ rRNA genes of the strains belonging to these two taxonomic units. The review also discusses other families outside the family Chlamydiaceae, which contain so-called Chlamydia-related or Chlamydia-like organisms. Members of each family share a 16S rDNA gene sequence similarity $>90 \%$. Furthermore, characterisation of the pathogenecity is presented, focusing especially on the representatives of the family Chlamydiaceae, which cause animal infections, and describing their zoonotic potential. Available data on this topic, connected with the representatives of other families, were mentioned.
\end{abstract}

Key words: Chlamydiales, taxonomy, pathogenicity, zoonotic potential.

Data available in the Polish literature on creating the order Chlamydiales, can be found in the publications by Pawlikowska and Deptula (27) and Truszczynski (40). At the beginning, type i.e. phylum Chlamydiae consisted of one family Chlamydiaceae separated from the order Rickettsiales into the created order Chlamydiales, according to Bergey (6). Based on the study of Wheelhouse and Longbottom (43), that resulted in re-classification of the Chlamydia in 1999, Everett et al. (13) displayed the data on creating four separate families within the order Chlamydiales, namely: Chlamydiaceae, Parachlamydiaceae, Simkaniaceae, and Waddliaceae. The authors introduced division of Chlamydia into two genera: Chlamydia and Chlamydophila, which was commonly accepted until recent years. Moreover, apart from four existing species: Chlamydia trachomatis, Chlamydophila pneumoniae, Chlamydophila psittaci, and Chlamydophila pecorum, they presented conclusions on creating five additional species: Chlamydia suis, Chlamydia muridarum, Chlamydophila abortus, Chlamydophila felis, and Chlamydophila caviae, within the concept. The division was based on phylogenetic analysis of the genes $16 \mathrm{~S}$ and 23S rRNA (43). It was additionally supported by phenotypic, morphological, and genetic properties of the microorganisms (43).

The above mentioned data were accepted by bacteriologists worldwide. In 2009, however, Stephens et al. (36) contested grounds for retaining the gender Chlamydophila. As a reason for re-connecting the two taxonomic units in one genus, the cited authors presented results of the comparative analysis of the genome of Chlamydia and Chlamydophila strains isolated from different hosts. The analysis revealed significant similarities among the studied strains, apart from several exceptions (Fig. 1). In 2011, these results were confirmed by Horn (20). Wheelhouse and Longbottom (43) presented the reversion to initially one genus Chlamydia, including nine currently known genera of the family Chlamydiaceae: Chlamydia $(C$.) trachomatis, C. muridarum, $C$. suis, $C$. pneumniae, $C$. psittaci, C. abortus, C. caviae, C. felis, and C. pecorum (20).

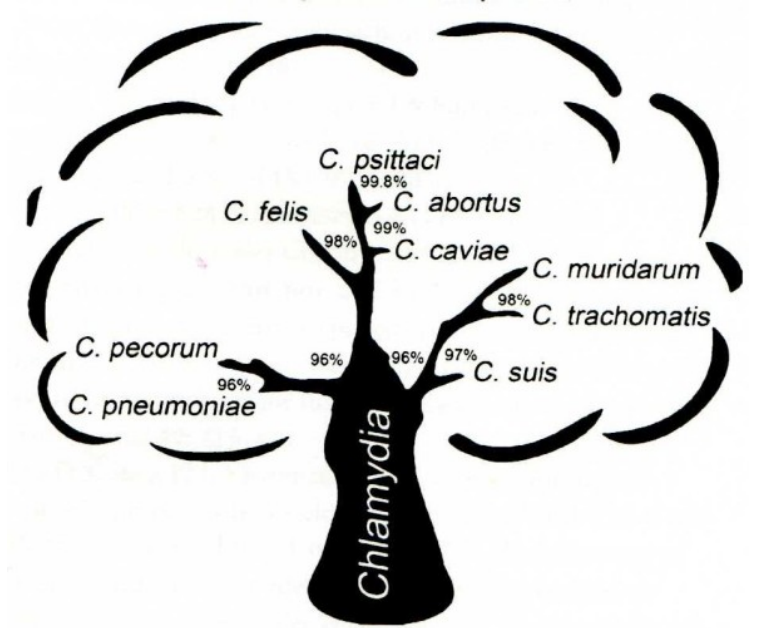

Fig. 1. Chlamydia species names showing percentage of 16S rRNA gene similarity between species (36). 
Apart from the typical Chlamydia belonging to the family Chlamydiaceae, seven families including Chlamydia-related or Chlamydia-like organisms were created (43). Representatives of the families were characterised by the $80 \%-90 \%$ similarity of the $16 \mathrm{~S}$ rDNA, sequence with Chlamydiaceae. Affinity to the family was based on the similarity higher than $90 \%$ of the gene sequence $16 \mathrm{~S}$ rDNA of the particular strains. The names of the families and corresponding genera and species as well as typical hosts (43) appear as follows: Candidatus Clavichlamydiaceae with the genus Candidatus Clavichlamydia and the species Candidatus Clavichlamydia Salmonicola - the main host salmonids; Criblamydiaceae with the genus Criblamydia and the species Criblamydia sequanensis and Estrella lausannensis occurring in the fluvial water; Parachlamydiaceae with the genus Parachlamydia and the species $P$. acanthamoebae - the main host Acantamoeba. Neochlamydia with the species $N$. hartmannella - the main host Hartmannella vermiformis, belongs to the family as well. The third genus of the family is Protochlamydia with the species Candidatus $P$. ameobophila - the host Acanthamoeba. Candidatus $P$. naegleriophila - the host Naegleria amoeba also belongs to the genus. The following family is Candidatus Piscichlamydiaceae with the genus Piscichlamydia and the species Candidatus Piscichlamydia salmonis, which occurs in salmon farms in the Atlantic Ocean. Next family is Rhabdochlamydiaceae with the genus Rhabdochlamydia and two species: Candidatus $R$. crassificans - the host arthropods (cockroaches), and Candidatus $R$. porcellionis - the host wood louse. The following family is Simkaniaceae with the genus Simkania and species S. negevensis. The next genus of the family is Candidatus Fritschea with two genera: Candidatus F. ericococci and Candidatus F. bernisiae the host insects. The eighth family including Chlamydiaceae, is the family Waddliaceae, with the genus Waddlia and the species $W$. chondrophila - host cattle, as well as the genus $W$. malaysiensis - host fruit bat.

The species from the family Chlamydiaceae can be characterised according to the degree of pathogenicity and zoonotic potential of Chlamydiales, which will be discussed in the next sections.

Among the species of the mentioned family, Chlamydia psittaci has the highest zoonotic potential. In birds it causes avian chlamydiosis. It occurs in true parrots (Psittacoidea), farm poultry, and wildfowl. Depending on the virulence of the infecting strains, the disease has acute or mild course in farm poultry. The infection can be asymptomatic as well, more frequently in older, rather than in younger birds (19). In Psittacoidea, increased internal body temperature, loss of appetite, diarrhoea, respiratory disorders, and conjunctivitis are frequently observed (30). In turkeys, serovar D of $C$. psittaci brings about exceptionally often the disease symptoms such as conjunctivitis, rhinitis, sinusitis, tracheitis, sacculitis, pericarditis, pneumonia, and enteritis. Persons having contact with poultry and ornamental birds are most exposed to the infection and disease. It concerns also personnel taking part in slaughter of turkeys (and other birds), and processing their products (41). Despite the facts that chlamydiosis in ducks is mostly asymptomatic, ducks can also constitute a source of the disease for humans (25). In humans, period of incubation lasts 1-2 weeks, sometimes it can be longer. The symptoms of the disease are atypical, and they are manifested by mild flu-like illness with an increased body temperature, headache, catarrh of the mucous membranes of the nose and throat, myalgia, and diarrhoea. Intermittently, endocarditis, encephalitis, and pneumonia can occur, which sometimes leads to death (28). In pregnant women, the infections from birds can bring about miscarriages (21).

Chlamydia abortus is an aetiological factor of enzootic abortion of ewes as it is a microorganism causing the most frequently occurring abortions in small ruminants. The losses caused by the disease are significant (31). C. abortus brings about infections in cattle, swine, roe-deer, and horses. Additionally, it constitutes a determined zoonotic risk causing intermittently, mild flu-like illness or, rarely, pneumonia in humans. In pregnant women, it can cause miscarriages $(22,35)$.

Chlamydia felis causes conjunctivitis in cats and humans, what indicates its zoonotic properties (39). The species is also considered as a rare cause of pneumonia in human (8).

Chlamydia pneumoniae is mainly a human pathogen, infecting mostly the lungs. It can be a factor, inter alia, complicating Alzheimer's disease (1), coronary disease (5), and arthritis (18). C. pneumoniae can be isolated from animals including amphibians, reptiles, and mammals (37). Genome analysis showed that the strains of $C$. pneumoniae occurring in people had primarily the animal origin; however, currently they remain and spread in humans without animal reservoir's participation (26).

The natural host of Chlamydia suis is swine (14) in which the species provokes or co-provokes conjunctivitis, sinusitis, pneumonia, enteritis, and reproduction disorders expressed by increased mortality of embryos or foetuses, as well as repeating heats. $C$. suis has a negative impact on sperm quality by decreasing motility of spermatozoa or causing their dying. Pigs, however, are first of all asymptomatic carriers of $C$. suis. Within the species, a considerable diversity of genome and genotype properties of the particular strains, including capacity to co-creating different syndromes in swine, was demonstrated (34).

Chlamydia pecorum is defined as a microorganism, which can induce or co-induce pneumonia, conjunctivitis, arthritis, enteritis, mastitis, metritis, encephalitis, and myelitis in swine, cattle, and koala (38).

Zoonotic potential of $C$. suis and $C$. pecorum has not been sufficiently determined so far (43).

In the following section, the pathogenicity for animals and zoonotic potential of Chlamydia-related microorganisms, also belonging to the order Chlamydiales, will be characterised. 
Waddliaceae. According to the data presented by Wheelhouse and Longbottom (43), twenty years have elapsed since the first isolation of Chlamydia-related microorganism from a case of bovine abortion in the USA (11). It was noted that the isolated organism had the life cycle similar to the representatives of Chlamydiaceae (23). Additionally, it caused bovine foetopathy. In calves not receiving colostrum, and in one-year-old goats, the infection caused temporary health disorders such as increased internal body temperature, leukopenia, and slowly developing but longer retaining anaemia (9). The classification using 16S rRNA gene analysis, determined the belonging of the germ to the order Chlamydiales with the name Waddlia chondrophila (33). Despite positive results in serological tests using the antigen $W$. chondrophila during the following years, participation of the organism in the abortions in cattle and calves was not confirmed (12). In 2011, three cases of abortions in cattle were noted in Switzerland, where $W$. chondrophila was identified with the use of RT-PCR and two of them were confirmed by immunohistochemical tests (3). Although this type of infections connected with abortions is sporadic, according to Wheelhouse and Longbottom (43), they occur more frequently than it is indicated in the documented and published data. Identification of the infectious causes of abortions in cows is not complete, when the identification of the germ is lower than $35 \%$ of cases, even when foetus and placenta are tested (7). W. chondrophila is presumably also a potential human pathogen. It multiplies in numerous kinds of human cells including macrophages as well as endometrium cells. It is assumed to participate in reproduction disorders in women (2). Moreover, it can take part in pneumonia in human (17) and inflammation of the upper respiratory tract in children (15).

Parachlamydiaceae. Recently conducted research with the use of molecular and immunohistochemical tests showed, according to Wheelhouse and Longbottom (43), the presence of the microorganisms of the genus Parachlamydia (4) in the cells of aborted bovine foetuses. The data were confirmed in Great Britain as well (10). However, to determine more precisely the role of the germs from the genus Parachlamydia in abortions in cattle, it is necessary to conduct research taking into account exclusively the microorganism and infections in pregnant cows. Only one publication indicates connection between Parachlamydia and abortions in small ruminants (32). The conducted tests identified the microorganisms only in $0.9 \%$ of examined goat samples. Swabs from eyes of sheep with conjunctivitis contained DNA of Parachlamydia, found also in swabs from eyes of healthy sheep (29). The strains Parachlamydia were detected in fluids from eyes of guinea pigs and cats (43).

More broad and precise studies were conducted on pathogenicity of Parachlamydiaceae in humans. At present, Parachlamydia acanthamoebae is considered as one of the pneumonia causes (16). DNA of Parachlamydia was identified in a number of cases of pulmonary diseases in newborns or complications related to the lungs in adults (24).
Rhabdochlamydiaceae. The family is represented by two species, which primarily were found in arthropods - Rhabdochlamydia porcellionis in woodlouse and $R$. crassificans in cockroaches. Recently, the microorganisms from the family Rhabdochlamydiaceae were isolated in $6 \%$ of samples from the cases of abortions in cattle (42). They are suspected to be responsible for pneumonia in humans and particularly in newborns (24).

In summary, this review presents the latest results of studies, conducted by a number of research groups, on the pathogenicity for animals and zoonotic properties of the representatives of the order Chlamydiales including mainly species of the family Chlamydiaceae and, to a lesser degree, Chlamydiarelated families. The data obtained so far clearly indicate that the knowledge in this field is incomplete and requires further investigations. It is possible that the broadly understood environment, including water reservoirs with inhabiting animals, constitute reservoirs of the microorganisms from the characterised group, which can pass to domestic animals in a way that is still undetermined, and cause or co-cause diseases, which have not been assigned to these pathogens so far. Moreover, their zoonotic potential also has not been fully elucidated. Therefore, it is clear that further research on pathogenicity and zoonotic properties of Chlamydiales, as well as the studies aiming at improvement of their taxonomy are continuously necessary.

\section{References}

1. Balin B.J., Lee M., Hammond C.J., Patel S., MacIntyre A., Little C.S., Appelt D.M.: The association of Chlamydia pneumoniae infection with pathological hallmarks of Alzheimer's disease. Neurobiol Aging 2004, 25, 436.

2. Baud D., Thomas V., Arafa A., Regan L., Greub G.: Waddlia chondrophila, a potential agent of human fetal death. Emerg Infect Dis 2007, 13, 1239-1243.

3. Blumer S., Greub G., Waldvogel A., Hassig M., Thoma R., Tschuor A., Pospischil A., Borel N.: Waddlia, Parachlamydia and Chlamydiaceae in bovine abortion. Vet Microbiol 2011, 152, 385-393.

4. Borel N., Ruhl S., Casson N., Kaiser C., Pospichil A., Greub G.: Parachlamydia spp. and related Chlamydialike organisms and bovine abortion. Emerg Infect Dis 2007, 13, 1904-1907.

5. Borel N., Summersgill J.T., Mukhopadhyay S., Miller R.D., Ramirez A., Pospischil A.: Evidence for persistent Chlamydia pneumoniae infection of human coronary atheromas. Atherosclerosis 2008, 199, 154-161.

6. Breed R.S., Murray E.G.D., Smith N.R.: Bergey's Manual of Determinative Bacteriology. The Williams and Wilkins Co., USA, 1974.

7. Cabell E.: Bovine abortion: aetiology and investigations. In Pract 2007, 29, 455-463.

8. Corsaro D., Venditti D., Valassina M.: New parachlamydial 16S rDNA phylotypes detected in human clinical samples. Res Microbiol 2002, 153, 563-567.

9. Crawford T.B., Dilbeck P.M., Kocan K.M., Stiller D., Evermann J.F., Kramer J.W., McGuire T.C.: Preliminary 
studies on a new Rickettsiaceae from an aborted bovine fetus. In: Proceedings of the $8^{\text {th }}$ Conference on Veterinary Hemoparasite Disease. St. Louis, 1989, pp. 121-127.

10. Deuchande R., Gidlow J., Caldow G., Baily J., Longbottom D., Wheelhouse N., Borel N., Greub G.: Parachlamydia involvement in bovine abortions in a beef herd in Scotland. Vet Rec 2010, 166, 598-599.

11. Dilbeck P.M., Evermann J.F., Crawford T.B., Ward A.C.S., Leathers C.W., Holland C.J., Mebus C.A., Logan L.L., Rurangirwa F.R., McGuire T.C.: Isolation of a previously undescribed Rickettsia from an aborted bovine fetus. J Clin Microbiol 1990, 28, 814-816.

12. Dilbeck-Robertson P., McAllister M.M., Broadway D., Evermann J.F.: Results of a new serologic test suggest an association of Waddlia chondrophila with bovine abortion. J Vet Diagn Invest 2003, 15, 568-569.

13. Everett K.D.E., Bush R.M., Andersen A.A.: Emended description of the order Chlamydiales, proposal of Parachlamydiaceae fam. nov. and Simkaniaceae fam. nov., containing one monotypic genus, revised taxonomy of the family Chlamydiaceae, including a new genus and five new species, and standards for the identification of organisms. Int J Syst Baceriol 1999, 49, 415-440.

14. Everett K.D.E.: Chlamydia and Chlamydiales: more than meets the eye. Vet Microbiol 2000, 75, 109-126.

15. Goy G., Croxatto A., Greub G.: Waddlia chondrophila enters and multiplies within human macrophages. Microbes Infect 2008, 10, 556-562

16. Greub G.: Parachlamydia acanthamoebae, an emerging agent of pneumonia. Clin Microbiol Infect 2009, 15, 1828.

17. Haider S., Collingro A., Walochnik J., Wanger M., Horn M.: Chlamydia-like bacteria in respiratory samples of community-acquired pneumonia patients. FEMS Microbiol Lett 2008, 281, 198-202.

18. Hannu T., Poulakkainen M., Leirisalo-Repo M.: Chlamydia pneumoniae as a triggering infection in reactive arthritis. Rheumatology (Oxford) 1999, 38, 411414.

19. Herrmann B., Person H., Jensen J.K., Joensen H.D., Klint M., Olsen B.: Chlamydophila psittaci in Fulmars, the Faroe Islands. Emerg Infect Dis 2006, 12, 330-332.

20. Horn M.: Phylum XXIV. Chlamydiae Garrity and Holt 2001. In: Krieg N.R., J.T. Staley, D.R. Brown, B.P. Hedlund, B.J. Pastor, N.L. Ward, W. Ludwig and W.B. Whitman (eds), Bergey's Manual of Systematic Bacteriology 2011, 4, 843-877.

21. Idu S.R., Zimmerman C., Mulder L., Meis J.F.: A very serious course of psittacosis in pregnancy. Ned Tijdschr Geneeskd 1998, 142, 2586-2589.

22. Johnson F.W.: Chlamydiosis. Br Vet J 1983, 139, 93101.

23. Kocan K.M., Crawford T.R., Dilbeck P.M., Evermann J.F., McGuire T.C.: Development of a Rickettsia isolated from an aborted bovine fetus. J Bacteriol 1990, 172, 5949-5955.

24. Lamoth F., Aeby S., Schneider A., Jaton-Ogay K., Vaudaux B., Greub G.: Parachlamydia and Rhabdochlamydia in premature neonates. Emerg Infect Dis $2009, \mathbf{1 5}, 2072-2075$.

25. Laroucau K., de Barbeyrac B., Vorimore F., Clerc M., Bertin C., Harkinezhad T., Verminnen K., Obeniche F., Capek I., Bebear C., Durand B., Zanella G., Vanrompay D., Garin-Bastuji B., Sachse K.: Chlamydial infections in duck farms associated with human casus of psittacosis in France. Vet Microbiol 2009, 135, 82-89.

26. Myers G.S., Mathews S.A., Eppinger M., Mitchell C., O'Brien K.K., White O.R., Benahmed F., Brunham R.C., Read T.D., Ravel J., Bavoil P.M., Times P.: Evidence that human Chlamydia pneumoniae was zoonotically acquired. J Bacteriol 2009, 191, 7225-7233.

27. Pawlikowska M., Deptuła W.: Chlamydie i chlamydofile u ludzi i zwierząt. Wyd Nauk Uniw Szczecińskiego, Szczecin 2012.

28. Petrovay F., Balla E.: Two fatal casus of psittacosis caused by Chlamydophila psittaci. J Med Microbiol 2008, 57, 1296-1298.

29. Polkinghorne A., Borel N., Becker A., Lu Z.H., Zimmermann D.R., Brugnera E., Pospischil A., Vaughan L.: Molecular evidence for chlamydial infections in the eyes of sheep. Vet Microbiol 2009, 135, 142-146.

30. Rodolakis A., Mohamad K.Y.: Zoonotic potential of Chlamydophila. Vet Microbiol 2010, 140, 382-391.

31. Rodolakis A., Salinas J., Papp J.: Recent advances on ovine chlamydial abortion. Vet Res 1998, 29, 275-288.

32. Ruhl S., Goy G., Casson N., Thoma R., Pospischil A., Greub G., Borel N.: Parachlamydia acanthamoebae infection and abortion in small ruminants. Emerg Infect Dis $2008, \mathbf{1 4}, 1966-1968$.

33. Rurangirwa F.R., Dilbeck P.M., Crawford T.B., McGuire T.C., McElwain T.F.: Analysis of the 16S rRNA gene of micro-organism WSU 86-1044 from an aborted bovine foetus reveals that it is a member of the order Chlamydiales: proposal of Waddliaceae fam. nov., Waddlia chondrophila gen. nov., sp. nov. Int J Syst Bacteriol 1999, 49, 577-581.

34. Schautteet K., Vanrompay D.: Chlamydiaceae infections in pig. Vet Res 2011, 42, 29.

35. Stepanek O., Jindrichova J., Horacek J., Krata V.: Chlamydiosis in cattle and in man: an epidemiologic and serologic study. J Hyg Epidemiol Microbiol Immunol 1983, 27, 445-459.

36. Stephens R.S., Myers G., Eppinger M., Bavoil P.M.: Divergence without difference: phylogenetics and taxonomy of Chlamydia resolved. FEMS Immunol Med Microbiol 2009, 55, 115-119.

37. Storey C., Lusher M., Yates P., Richmond S.: Evidence for Chlamydia pneumoniae of non-human origin. J Gen Microbiol 1993, 139, 2621-2626.

38. Storz J.: Overview of animal diseases induced by chlamydial infections. In: Microbiology of Chlamydia. Editor Barron A.L., CRC Press, Boca Raton, 1988, pp. 167-192.

39. Sykes J.E.: Feline chlamydiosis. Clin Tech Small Anim Pract 2005, 20, 129-134.

40. Truszczyński M.: Bakteriologia weterynaryjna. PWRL, Warszawa, 1984.

41. Vanrompay D., Mast J., Ducatelle R., Haesebrouck F., Goddeeris B.: Chlamydia psittaci in turkeys: pathogenesis of infections in avian serovars A, B and D. Vet Microbiol 1995, 47, 245-256.

42. Wheelhouse N., Katzer F., Wright F., Longbottom D.: Novel Chlamydia-like organisms as cause of bovine abortions UK. Emerg Infect Dis 2010, 16, 1323-1324.

43. Wheelhouse N., Longbottom D.: Endemic and emerging chlamydial infections of animals and their zoonotic implications. Transbound Emerg Dis 2012, 59, 283-291. 